\title{
PEMANFAATAN ZEOLIT ALAM TERMODIFIKASI SURFAKTAN HDTMA-Br (HEXADECYLTRIMETHYLAMMONIUM BROMIDE) SEBAGAI ADSORBEN ANION NITRAT $\left(\mathrm{NO}_{3}{ }^{-}\right)$
}

\author{
Pandu Jati Laksono \\ Universitas Islam Negeri Raden Fatah Palembang \\ E-mail: pandujati_uin@ radenfatah.ac.id
}

\begin{abstract}
Abstrak: Penelitian ini bertujuan: (1) Mengetahui zeolit termodifikasi surfaktan HDTMA-Br dapat menyerap anion anorganik toksik nitrat $\left(\mathrm{NO}_{3}{ }^{-}\right)$, (2) Mengetahui waktu kontak optimum yang dibutuhkan untuk penyerapan anion anorganik toksik $\mathrm{NO}_{3}^{-}$oleh zeolit alam termodifikasi surfaktan HDTMA-Br (3) Mengetahui konsentrasi surfaktan optimum yang dibutuhkan untuk penyerapan anion anorganik toksik $\mathrm{NO}_{3}{ }^{-}$oleh zeolit alam termodifikasi surfaktan HDTMA-Br. Penelitian ini menggunakan metode eksperimen. Zeolit yang digunakan adalah zeolit alam yang berasal dari Wonosari Klaten. Zeolit alam termodifikasi surfaktan HDTMA-Br dikarakterisasi dengan FTIR dan SEM: (1) karakterisasi menggunakan FTIR untuk mengetahui gugus fungsi yang ada dalam zeolit, (2) SEM untuk menentukan struktur permukaan dari zeolit (3) Penentuan kadar terserap anion nitrat oleh zeolit alam termodifikasi surfaktan HDTMA-Br dilakukan dengan menggunakan spektroskopi Uv-vis. Kesimpulannya adalah: (1) zeolit termodifikasi surfaktan HDTMA-Br dapat digunakan sebagai adsorben anion nitrat $\left(\mathrm{NO}_{3}{ }^{-}\right)$, (2) waktu kontak optimum yang sesuai untuk adsorpsi anion nitrat $\left(\mathrm{NO}_{3}{ }^{-}\right)$oleh adsorben zeolit termodifikasi surfaktan HDTMA-Br adalah 40 menit (3) konsentrasi surfaktan optimum yang sesuai untuk adsorpsi anion nitrat $\left(\mathrm{NO}_{3}{ }^{-}\right)$oleh adsorben zeolit termodifikasi surfaktan HDTMA-Br adalah $5 \mathrm{~g} / \mathrm{L}$ dengan penyerapan anion nitrat $\left(\mathrm{NO}_{3}{ }^{-}\right)$sebesar $75,13 \%$.
\end{abstract}

Kata kunci: modifikasi, zeolit, surfaktan HDTMA-Br, adsorpsi, nitrat

\section{PENDAHULUAN}

Di Indonesia sendiri keberadaan zeolit sangat melimpah. Akan tetapi pemanfaatannya belum begitu maksimal. Sehingga perlu dilakukan cara untuk memanfaatkan zeolit di Indonesia. Salah satunya yaitu memanfaatkan zeolit sebagai penyerap anion anorganik. Secara umum zeolit dipergunakan sebagai adsorben dalam proses pemisahan dan pemurnian. Disamping bentuknya yang alami, permukaan zeolit yang termodifikasi juga dapat digunakan untuk menghilangkan polutan air seperti nitrat.

Kemampuan adsorpsi zeolit alam dapat ditingkatkan secara intensif dengan cara impregnasi menggunakan substansi yang cocok seperti surfaktan. Perlakuan pada zeolit alam dengan surfaktan kationik mengubah permukaannya secara kimia yaitu yang semula bermuatan negatif diubah menjadi bermuatan positif (Masukume, Maurice, Ochieng, \& Otieno, 2011), sehingga dengan pengubahan muatan pada zeolit yang semula negatif menjadi positif diharapkan dapat menyerap anion Nitrat $\left(\mathrm{NO}_{3}{ }^{-}\right)$yang bermuatan negatif.

Nitrat merupakan senyawa yang penting dalam bentuk ini nitrogen merupakan senyawa yang lebih mudah diserap tanaman berarti pengaruhnya secara langsung terhadap produktivitas perairan.Sumber senyawa nitrogen di waduk selain di waduk itu sendiri juga berasal dari limbah pertanian (karena limbah pertanian mengandung nitrat yang ada pada pupuk), rumah tangga, dan indusrti. Dalam keadaan aerob dengan bantuan bakteri, amoniak diubah menjadi 
nitrat menjadi nitrit di mana nitrat digunakan oleh tumbuhan terutama alga serta produser primer lainnya.

Perairan dalam usaha pengelolaannya meliputi juga salah satu usaha pembentukan lingkungan yang dapat menunjang kebersihan dari pencemaran terutama limbah rumah tangga oleh penduduk setempat serta kemampuan perairan menyediakan dan mempertahankan kualitas dan kuntitas produktifitas sehingga keseimbangan ekosistem dapat lebih terjamin (Syahrudin, 2000)

Proses aktivasi zeolit dapat dilakukan dengan metode secara fisika dan kimia. Aktivasi secara fisika dapat dilakukan dengan cara memperkecil ukuran untuk memperluas permukaan dan pemanasan pada suhu tinggi. Aktivasi secara kimia dilakukan dengan penambahan asam yang mengakibatkan terjadinya pertukaran kation dengan $\mathrm{H}^{+}$(Lestari,2010). Proses pertukaran ion sering digunakan karena metode ini sangat sederhana, tidak menghasilkan limbah buangan padat dan dapat dilakukan proses regenerasi dengan cara aktivasi (Marsidi,rach 2001).

Salah satu bahan pencemar air adalah nitrat. Peningkatan nitrat di dalam tanah dan air terutama disebabkan oleh pemakaian pupuk secara intensif. Pencemaran nitrat disebabkan air limbah pertanian mengandung senyawa nitrat akibat penggunan pupuk nitrogen (urea). Nitrat yang berlebih akan masuk ke dalam air tanah dan air sungai (Manampiring, 2009). Konsumsi air yang mengandung nitrat yang berlebihan dapat menyebabkan gangguan GI (gastrointestinal), diare bercampur darah, coma dan bila tidak ditolong dapat mengakibatkan kematian. Nitrat juga dapat menyebabkan kanker lambung dan methemoglobinemia pada bayi atau yang dikenal dengan penyakit blue babies. WHO pada tahun 2007 mencatat 2000 kasus bayi biru diberbagai negara karena bayi tersebut diberi air minum yang mengandung $20 \mathrm{mg}$ nitrat/L air. Pada keracunan akut menyebabkan meningitis, diikuti oleh stupor, coma dan kematian (Rachman, 2009).

\section{METODOLOGI PENELITIAN}

\section{Bahan Penelitian}

Sampel dalam penelitian ini adalah zeolit alam yang berasal dari Wonosari Klaten. Zeolit alam, aquades, aquabides, larutan HF, HDTMA-Br, larutan $\mathrm{HCl}$, larutan $\mathrm{CHCl}_{3}$, kristal $\mathrm{KNO}_{3}$

\section{Alat Penelitian}

Peralatan yang digunakan anatara lain : gelas ukur, gelas beker, labu ukur, labu ukur, labu ukur, pipet tetes, tabung reaksi, kaca arloji , neraca analitik, oven, alu, mortir, pengaduk kaca, baskom, toples, ayakan 120 mesh, corong kaca, magnet stirrer, kertas saring, indikator $\mathrm{pH}$ universal, botol kaca, vacuum filter, spektroskopi FT-IR, SEM, Spektroskopi UV-Vis

\section{Tahapan karakterisasi dan pengontakan zeolit \\ a. Preparasi Zeolit}

Pada tahap awal zeolit dipersiapkan terlebih dahulu dengan cara mempersiapkan 250 gram serbuk zeolit, mengayak serbuk zeolit hingga lolos 
ayakan 120 mesh; menyuci dengan 1 liter akuades disertai dengan pengadukan kemudian membuang air penyucinya, mengulang pencucian dengan akuades sebanyak 3 kali pencucian, memanaskan serbuk zeolit yang telah dicuci dalam oven dengan suhu $120^{\circ} \mathrm{C}$ hingga benar-benar kering, kemudian mendinginkan serbuk zeolit yang telah di oven hingga suhu ruangan.

\section{b. Aktivasi Zeolit Alam}

Aktivasi kepada zeolit dilakukan dengan merendam serbuk zeolit ke dalam larutan HF 1\% dengan perbandingan volume 1:2 dalam wadah plastik selama 10 menit pada temperatur kamar, menyaring dan mencuci berulang-ulang dengan akuades hingga $\mathrm{pH}$ zeolit sama dengan akuades dengan cara mendekantasi, mengeringkan zeolit netral dalam oven pada temperatur $110^{\circ} \mathrm{C}$ selama 3 jam, menggerus serbuk zeolit alam, menghasilkan serbuk zeolit alam yang siap untuk dimodifikasi.

\section{c. Modifikasi zeolit dengan Surfaktan HDTMA-Br}

Modifikasi zeolit dilakukan agar bisa bersifat kationik dilakukan dengan membuat larutan surfaktan HDTMA-Br $1 \mathrm{~g} / \mathrm{L}$, mencampurkan zeolit teraktivasi sebanyak 5 gram dengan larutan surfaktan HDTMA-Br dengan perbandingan 1:10, campuran diaduk dengan stirer dengan kecepatan 6 rpm selama 3 jam, menyaring larutan campuran hasil pengadukan menggunakan vacuum filter, mengeringkan residu dengan oven listrik pada suhu $65^{\circ} \mathrm{C}$, menghaluskan zeolit hingga menjadi serbuk sehingga adsorben zeolit sudah termodifikasi surfaktan kationik.

\section{d. Uji Karakterisasi}

Zeolit yang sudah diaktivasi kemudian dianalisis menggunakan spektrofotometer FTIR dan SEM

\section{e. Pengkontakan Zeolit termodifikasi HDTMA-Br dengan larutan nitrat standar 2 ppm menggunakan metode Batch.}

Pada tahap selanjutnya dilakukan pengontakan dengan nitrat standar dengan cara mencampurkan zeolit termodifikasi dengan $100 \mathrm{ml}$ larutan standar nitrat 2ppm, mengaduk larutan campuran dengan stirer dengan kecepatan $6 \mathrm{rpm}$ selama 60 menit, menyaring larutan hasil pengkontakan dengan kertas saring, memasukan filtrat ke dalam botol dan menambahkan $\mathrm{HCl} 1 \mathrm{~N}$, mengukur absorbansi larutan nitrat dengan Spektrofotometer UV- VIS pada $\lambda 220 \mathrm{~nm}$ (pengukuran dilakukan dengan triplo pengukuran).

\section{HASIL DAN PEMBAHASAN}

\section{Tahap Karakterisasi}

\section{A. Hasil Analisis FTIR}

Pada tahap ini, serbuk zeolit yang sudah dimodifikasi kemudian dianalisis menggunakan Spektrofotometer Inframerah. Hal ini dilakukan untuk memastikan secara kualitatif keberhasilan proses aktivasi. Spektra IR menghasilkan informasi 
struktur material yang sedang dipelajari.

Secara spektroskopis, zeolit dapat diamati pada rentang daerah bilangan gelombang 300-1300 $\mathrm{cm}^{-1}$. Panjang gelombang tersebut merupakan daerah utama serapan ikatan tetrahedral dari komponen utama penyusun zeolit yaitu $\mathrm{SiO}_{4}$ dan $\mathrm{AlO}_{4}$. Pita pada $300-420 \mathrm{~cm}^{-1}$ merupakan daerah untuk pore opening pada external linkage. Rentangan simetri O-Al-O atau O-Si-O pada internal tetrahedral akan muncul pada $650-720 \mathrm{~cm}^{-1}$ sedang untuk external linkage akan muncul pada $750-820 \mathrm{~cm}^{-1}$. Tekukan Si-O atau Al-O akan muncul pada daerah $420-500 \mathrm{~cm}^{-1}$ (Wietkamp dan Puppe, 1999:7). Pita serapan pada daerah 1041,5-1087,13 $\mathrm{cm}^{-1}$ menunjukkan rentangan asimetri Al-O dan pada $1639,4-1643,02 \mathrm{~cm}^{-1}$ menunjukan rentangan asimetri Si-O. Ikatan ulur O-H muncul pada daerah $3200-3600 \mathrm{~cm}^{-1}(\mathrm{Sri}$ Warsito, 2007:10).

Dari gambar 4.1 terlihat bahwa terjadi penurunan intensitas pada rentangan asimetri Si-O yang ditunjukkan bilangan gelombang $1635,64 \mathrm{~cm}^{-1}$ pada zeolit teraktivasi dibanding zeolit alam. Hal ini menunjukan terjadinya proses aktivasi dimana HF mengatur ulang letak atom dalam kerangka zeolit dengan mengikat $\mathrm{Si}$ dalam zeolit. Hal ini mengakibatkan penurunan intensitas rentangan asimetri $\mathrm{Si}-\mathrm{O}$ dalam zeolit teraktivasi.

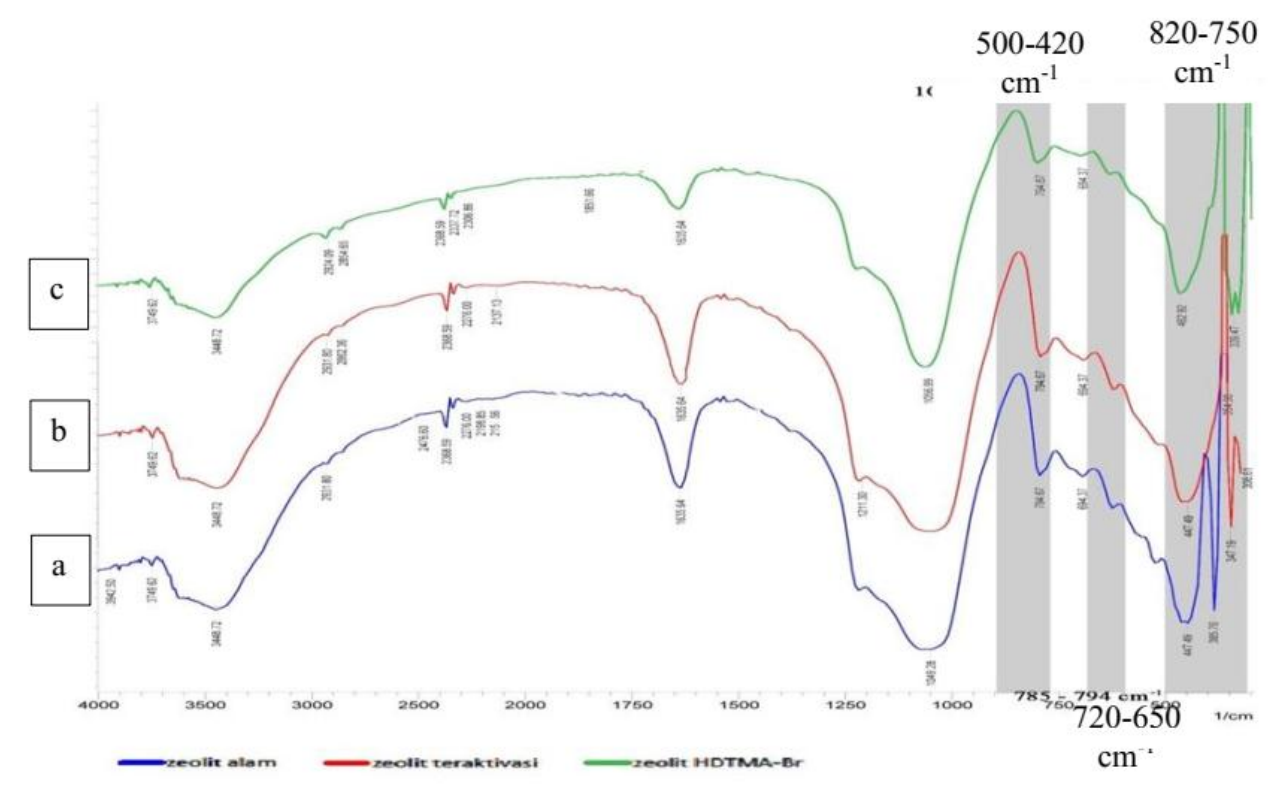

Gambar 1. Spektra FTIR Zeolit Alam (a), Zeolit teraktivasi(b) dan Zeolit Termodifikasi HDTMA-Br (c)

Pada zeolit termodifikasi surfaktan, muncul pita pada daerah 2800-3000 $\mathrm{cm}^{-1}$. Dimana pita zeolit termodifikasi HDTMA ${ }^{+}$akan muncul pada bilangan gelombang 2924,09 $\mathrm{cm}^{-1}$ dan 2854,65 $\mathrm{cm}^{-1}$. Hal ini sesuai dengan rentangan simetri dan asimetri $\mathrm{CH}_{2}$ dari amina (Hongping, Ray, Jianxi, 2004). Frekuensi pita absorbsi rentangan $\mathrm{CH}_{2}$ dari rantai amina sangat sensitif terhadap perubahan konformasi dari rantai dan hanya ketika rantai pada high ordered (all trans conformatanions) pita adsorbsi yang sempit berada pada sekitar $2916 \mathrm{~cm}^{-1}$ (sebagai n $\left(\mathrm{CH}_{2}\right)$ ) dan $2848 \mathrm{~cm}^{-1}$ (sebagai $\mathrm{n}\left(\mathrm{CH}_{2}\right)$ ) pada spektrum infra merah. 
Pada kisaran konsentrasi tinggi, pita rentangan $\mathrm{CH}_{2}$ asimetris relatif konstan dan berada pada all trans conformatanions. Pada konsentrasi rendah frekuensi bergeser secara signifikan pada bilangan gelombang yang lebih tinggi. Rentangan simetris $\mathrm{CH}_{2}$ pada FTIR mengalami pergeseran. Menurut Hongping, dkk (2004: 5) rentangan simetris $\mathrm{CH}_{2}$ sedikit sensitif terhadap konformasi rantai. Pada bilangan gelombang $2368,56 \mathrm{~cm}^{-1}$ dan $2306,86 \mathrm{~cm}^{-1}$ menunjukkan HDTMA-Br telah terikat dengan zeolit kemudian pada $1835,54 \mathrm{~cm}^{-1}$ menunjukkan bahwa $\mathrm{Si}$ berkurang.

\section{B. Scanning Electron Microscope (SEM)}

Scanning Electron Microscope (SEM) merupakan mikroskop elektron yang memiliki perbesaran tinggi sampai dengan 20000X untuk keperluan analisis dalam tampilan gambar dengan kemampuan untuk melihat struktur permukaan suatu mineral (benda uji) secara 3 dimensi.

Hasil karakterisasi zeolit alam maupun yang termodifikasi dapat dilihat pada gambar 2. Melalui perbesaran hingga 20.000X, terlihat bahwa pada permukaan zeolit alam (ZA) gambar (a) masih terdapat banyak impuritas dibandingkan dengan permukaan zeolit teraktivasi (ZT). Pada pada gambar (b) dengan permukaan yang lebih bersih juga terlihat bahwa surfaktan HDTMA-Br dapat menempel pada permukaan zeolit. Hal ini terlihat pada gambar (c) yaitu adanya bintik-bintik putih yang tampak dipermukaan zeolit.
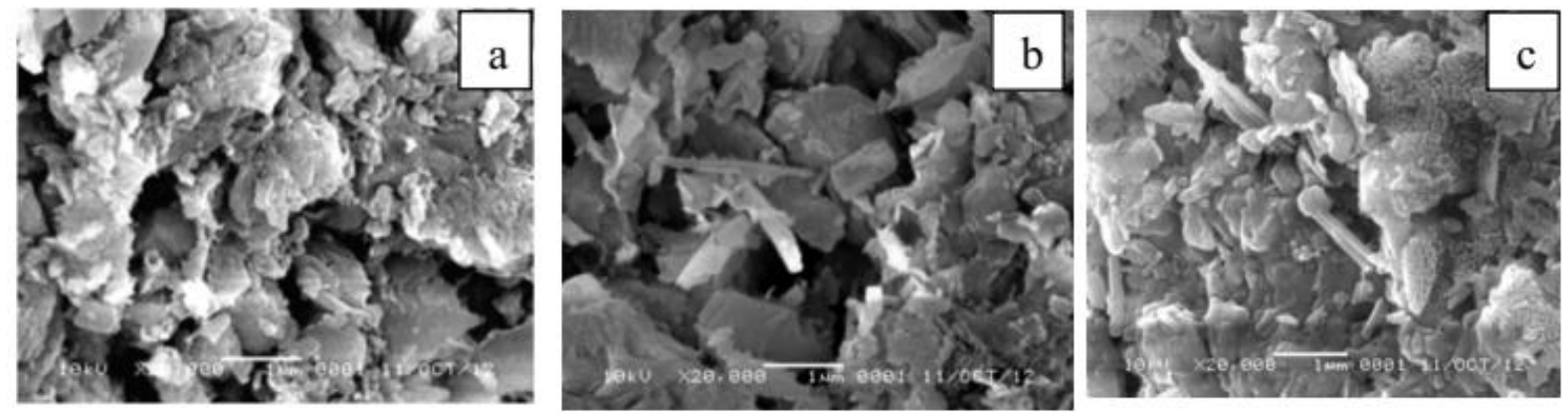

Gambar 2. Karakterisasi SEM dari ZA (a), ZT (b), ZHDTMA-Br(c)

\section{Pemanfaatan Zeolit Termodifikasi HDTMA-Br untuk Mengadsorbsi}

\section{Anion Nitrat}

Untuk mengetahui pemanfaatan zeolit dilakukan uji adsorpsi dalam penelitian ini yaitu meliputi pengontakan dengan anion nitrat yang dilakukan setelah zeolit dimodifikasi menggunakan surfaktan HDTMA-Br dan setelah dikarakterisasi. Anion nitrat yang digunakan berupa limbah buatan dalam skala laboratorium. Larutan nitrat dibuat dengan melarutkan serbuk kalium nitrat dalam akuades sesuai dengan metode SNI. Sebelum proses adsorpsi, larutan nitrat dianalisis terlebih dahulu menggunakan spektrofotometer UV-Vis. Langkah pertama yaitu menentukan panjang gelombang $(\lambda)$ maksimal. Pada penelitian ini, panjang gelombang $(\lambda)$ maksimal yang didapat yaitu $220 \mathrm{~nm}$. Kemudian membuat 
kurva kalibrasi dengan konsentrasi larutan standar 1 ppm, 2 ppm, 3 ppm, 4 ppm, dan 5 ppm.

Untuk mengetahui apakah zeolit termodifikasi surfaktan HDTMA-Br dapat digunakan sebagai adsorben nitrat $\left(\mathrm{NO}_{3}^{-}\right)$dilakukan dengan mengukur absorbansi larutan anion nitrat yang telah diadsorpsi menggunakan zeolit termodifikasi surfaktan HDTMA-Br, kemudian dianalisis dengan hukum Lambert Beer. Dari analisis konsentrasi didapatkan kemungkinan bahwa setelah diadsorpsi ternyata konsentrasi larutan anion nitrat $\left(\mathrm{NO}_{3}{ }^{-}\right)$lebih sedikit dibandingkan konsentrasi awal. Reaksi yang terjadi pada saat proses pengontakan zeolit termodifikasi surfaktan HDTMA-Br dengan anion nitrat yaitu sebagai berikut:

Zeolit $-\mathrm{R} \mathrm{N}\left(\mathrm{CH}_{3}\right)_{3}{ }^{+}+\mathrm{Br}^{-}+\mathrm{KNO}_{3} \rightarrow$ Zeolit $-\mathrm{RN}\left(\mathrm{CH}_{3}\right)_{3}{ }^{+}\left[\mathrm{NO}_{3}\right]^{-}+\mathrm{KBr}$

Sumber: (Novitasari ,2013)

Berdasarkan reaksi diatas dapat diketahui bahwa prinsip utama penyerapan anion nitrat $\left(\mathrm{NO}_{3}{ }^{-}\right)$ke dalam zeolit yaitu melalui pertukaran anion. Anion-anion yang berada pada permukaan zeolit termodifikasi, yaitu $\mathrm{Br}^{-}$digantikan oleh anion nitrat $\left(\mathrm{NO}_{3}^{-}\right)$dari $\mathrm{KNO}_{3}$.

Adsorbsi merupakan peristiwa penyerapan suatu zat pada permukaan zat lain. Zat yang diserap disebut fase terserap (adsorbat), sedangkan zat yang menyerap disebut adsorbens. Dalam proses adsorbsi dipengaruhi oleh banyak faktor, seperti waktu kontak, karakteristik adsorben, kelarutan adsorbat, temperatur dan massa adsorben. Dalam penelitian ini akan ditentukan waktu kontak optimum zeolit termodifikasi surfaktan HDTMA-Br ditinjau dari banyaknya anion nitrat yang terserap. Perhitungan Efektivitas Adsorpsi Ion Nitrat :

dimana:

$$
\% \mathrm{NO}_{3}{ }^{-} \text {teradsorpsi }=\frac{\mathrm{Co}-\mathrm{C}}{\mathrm{Co}} \times 100 \%
$$

Co $=$ konsentrasi nitrat $\left(\mathrm{NO}_{3}{ }^{-}\right)$sebelum proses adsorpsi

$\mathrm{C}=$ konsentrasi nitrat $\left(\mathrm{NO}_{3}{ }^{-}\right)$setelah proses adsorpsi

Zeolit dengan berbagai konsentrasi kemudian dikontakkan dengan variasi waktu dari 10 menit, 20 menit, 30 menit, 40 menit, 50 menit dan 60 menit. Didapatkan data konsentrasi nitrat sebelum dan sesudah dikontakkan kemudian dihitung kadar nitrat yang teradsorpsi. Grafik dibawah ini menunjukkan hubungan waktu kontak dengan kadar terserap anion nitrat : 


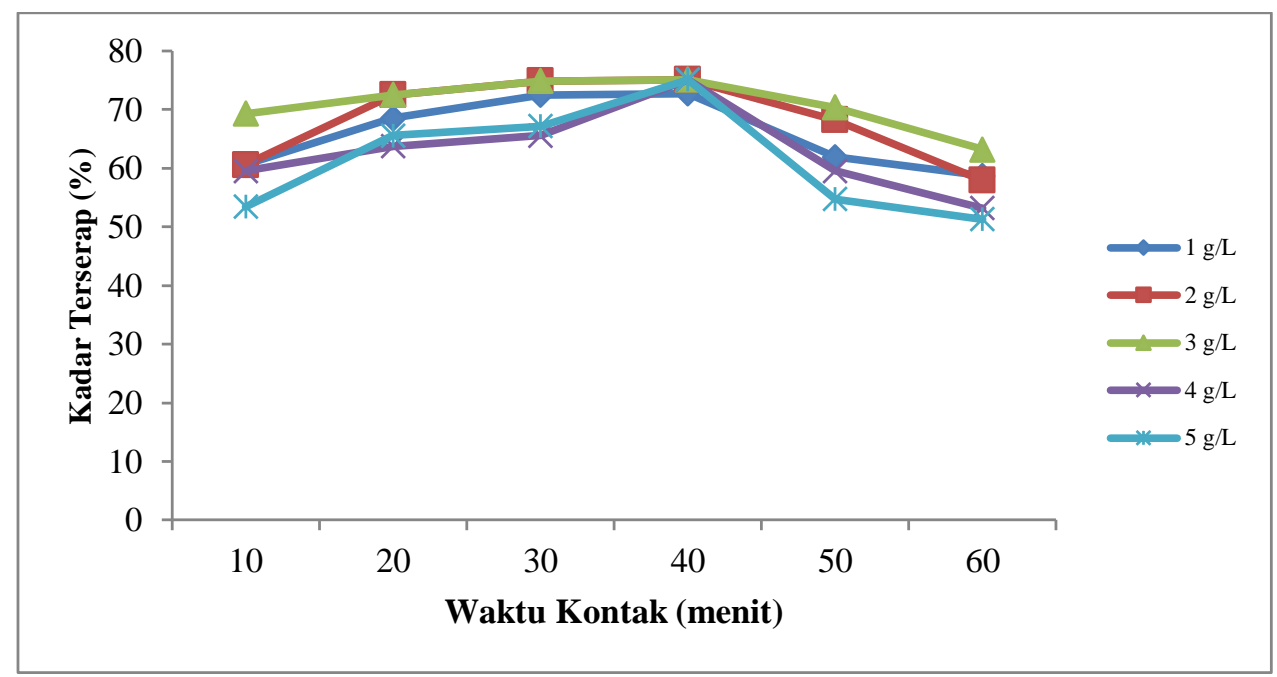

Gambar 3. Grafik Hubungan Waktu Kontak dengan Kadar Terserap Anion Nitrat dalam Berbagai Konsentrasi

Pada waktu kontak 10 menit pada konsentrasi surfaktan 1 g/L, 2 g/L,3 g/L, $4 \mathrm{~g} / \mathrm{L}$ dan $5 \mathrm{~g} / \mathrm{L}$ kadar penyerapan nitrat berturut adalah $60,58 \% ; 60,58 \% ; 69,31 \%$; $59,52 \%$ dan $53,43 \%$, dalam waktu ini terlihat persamaan penyerapan pada kosentrasi $1 \mathrm{~g} / \mathrm{L}$ dan $2 \mathrm{~g} / \mathrm{L}$ sedangkan kadar penyerapan tertinggi pada konsentrasi $3 \mathrm{~g} / \mathrm{L}$ kemudian kadar penyerapan turun pada konsentrasi $4 \mathrm{~g} / \mathrm{L}$ dan $5 \mathrm{~g} / \mathrm{L}$.

Pada waktu kontak 20 menit pada konsentrasi surfaktan $1 \mathrm{~g} / \mathrm{L}, 2 \mathrm{~g} / \mathrm{L}, 3$ $\mathrm{g} / \mathrm{L}, \quad 4 \mathrm{~g} / \mathrm{L}$ dan $5 \mathrm{~g} / \mathrm{L}$ kadar penyerapan nitrat berturut adalah 68,51\%; $72,48 \% ; 72,48 \% ; 63,75 \%$ dan 65,60\%, dalam waktu 20 menit konsentrasi $1 \mathrm{~g} / \mathrm{L}$ terlihat kadar terserap $68,51 \%$ bukanlah kadar terendah penyerapan nitrat pada waktu ini, kemudian terlihat persamaan penyerapan pada kosentrasi 2 g/L dan 3 g/L yang merupakan kadar penyerapan tertinggi kemudian kadar penyerapan turun pada konsentrasi $4 \mathrm{~g} / \mathrm{L}$ yang merupakan kadar terendah penyerapan nitrat pada waktu 20 menit dan naik lagi di konsentrasi $5 \mathrm{~g} / \mathrm{L}$.

Pada waktu kontak 30 menit dengan konsentrasi surfaktan 1 g/L , 2 g/L,3 $\mathrm{g} / \mathrm{L}, \quad 4 \mathrm{~g} / \mathrm{L}$ dan $5 \mathrm{~g} / \mathrm{L}$ kadar penyerapan nitrat berturut adalah 72,48\%; $73,01 \% ; 73,01 \% ; 65,60 \%$ dan $67,61 \%$, dalam waktu ini terlihat persamaan penyerapan pada kosentrasi $2 \mathrm{~g} / \mathrm{L}$ dan $3 \mathrm{~g} / \mathrm{L}$ yang merupakan kadar penyerapan tertinggi kemudian kadar penyerapan $1 \mathrm{~g} / \mathrm{L}$ lebih tinggi dari kadar penyerapan dengan konsentrasi $4 \mathrm{~g} / \mathrm{L}$ yang merupakan kadar terendah penyerapan nitrat pada waktu 20 menit dan naik lagi di konsentrasi $5 \mathrm{~g} / \mathrm{L}$.

Pada waktu kontak 40 menit dengan konsentrasi surfaktan $1 \mathrm{~g} / \mathrm{L}, 2 \mathrm{~g} / \mathrm{L}, 3$ $\mathrm{g} / \mathrm{L}, \quad 4 \mathrm{~g} / \mathrm{L}$ dan $5 \mathrm{~g} / \mathrm{L}$ kadar penyerapan nitrat berturut adalah 72,75\%; 73,80\%;73,28\%;73,80\% dan 75,13\%. Pada konsentrasi $2 \mathrm{~g} / \mathrm{L}$ dan $4 \mathrm{~g} / \mathrm{L}$ terjadi persamaan kadar penyerapan, kemudian kadar tertinggi penyerapan nitrat dalam waktu 40 menit terjadi pada konsentrasi $5 \mathrm{~g} / \mathrm{L}$ dan kadar terendahnya pada konsentrasi $1 \mathrm{~g} / \mathrm{L}$. Pada waktu kontak ini terjadi penyerapan paling tinggi pada semua konsentrasi surfaktan. Dari grafik dapat dilihat pada waktu kontak ini penyerapannya merupakan titik paling tinggi kemudian turun di titik selanjutnya waktu kontak selanjutnya. 
Pada waktu kontak 50 menit dengan konsentrasi surfaktan 1 g/L , 2 g/L,3 $\mathrm{g} / \mathrm{L}, \quad 4 \mathrm{~g} / \mathrm{L}$ dan $5 \mathrm{~g} / \mathrm{L}$ kadar penyerapan nitrat berturut adalah 61,90\%; $68,25 \% ; 70,37 \% ; 59,52 \%$ dan 54,76\%. Pada waktu ini terjadi penurunan kadar penyerapan nitrat setelah 50 menit waktu pengontakan, hal ini terlihat dari kelima konsentrasi surfaktan tersebut terjadi penurunan kadar penyerapan nitrat jika dibandingkan kadar penyerapan pada waktu kontak sebelumnya yang grafiknya naik dari waktu kontak 10 menit sampai 40 menit, pada waktu kontak ini mulai mengalami penurunan.

Pada waktu kontak 60 menit dengan konsentrasi surfaktan 1 g/L , 2 g/L,3 $\mathrm{g} / \mathrm{L}, \quad 4 \mathrm{~g} / \mathrm{L}$ dan $5 \mathrm{~g} / \mathrm{L}$ kadar penyerapan nitrat berturut adalah 58,73\%; $57,93 \% ; 63,22 \% ; 53,17 \%$ dan 51,32\%. Pada waktu ini kadar nitrat yang terserap secara keseluruhan adalah yang paling rendah bila dibandingkan dengan waktu kontak lainnya hal ini mungkin karena nitrat yang terserap oleh zeolit sudah optimum dan mengalami penurunan dalam kemampuan penyerapan atau bisa jadi karena pori maupun rongga nitrat sudah penuh ditempeli anion nitrat. Penurunan laju adsorpsi diakibatkan oleh kemampuan adsorben dalam mengadsorpsi semakin berkurang hingga pada waktu tertentu adsorben tidak dapat menyerap logam lagi yang ditunjukkan oleh penurunan kapasitas adsorpsi.

Kemampuan aadsorben menyerap yang menurun seiring berjalannya waktu serupa dengan penelitian yang dilakukan (Emelda,Putri, \& Ginting, 2013) tentang pemanfaatan zeolit alam teraktivasi untuk adsorpsi logam $\mathrm{Cr}^{3+}$ dimana sisi aktif dari adsorben sudah terisi oleh logam hingga adsorbennya jenuh dan tidak mampu lagi menyerap logam. Waktu untuk mencapai keadaan,setimbang pada proses serapan logam oleh adsorben berkisar antara beberapa menit hingga beberapa jam (Khasanah, 2009).

Pada grafik terlihat bahwa waktu kontak 40 menit merupakan waktu tertinggi terserapnya anion nitrat. Hal ini dimungkinkkan zeolit sudah mencapai titik optimum dalam menyerap nitrat sedangkan pada waktu kontak selanjutnya yaitu pada menit ke 50 dan 60 mengalami penurunan baik secara drastis maupun tidak hal ini dimungkinkan karena zeolit sudah tepat jenuh atau sudah tak dapat menyerap nitrat lagi karena semua rongganya sudah terisi. Lamanya waktu kontak memungkinkan proses difusi dan penempelan molekul adsorbat berlangsung lebih baik kecuali setelah mencapai optimum.

Konsentrasi merupakan hal yang sangat menentukan dalam proses adsorpsi, karena jumlah zat yang terserap setiap berat adsorbens, tergantung konsentrasi dari zat terlarut. Namun demikian, bila adsorbens sudah jenuh, konsentrasi tidak lagi berpengaruh. Adsorpsi dan desorpsi (pelepasan) merupakan kesetimbangan sehingga semakin tinggi konsentrasi maka zat nitrat yang terserap juga semakin banyak.

Naik turunnya kadar penyerapan ini bisa terjadi karena adanya faktor yang mempengaruhinya selain dari konsentrasi surfaktan, yaitu dari adsorben zeolit yang sudah maksimum menyerap anion nitrat dan anion nitrat yang mengalami penurunan konsentrasi saat proses adsorbsi (konsentrasi nitrat mulai habis) akan tetapi berdasar grafik ini faktor yang lebih utama selain dari konsentrasi surfaktan adalah kemampuan zeolit dalam menyerap nitrat sudah optimal karena bila faktor konsentrasi nitrat yang mulai habis maka penurunannya seharusnya sangat tinggi 
bahkan sangat rendah kadar penyerapannya karena sudah mulai habisnya konsentrasi nitrat yang terserap. Konsentrasi tertinggi penyerapan nitrat terdapat pada konsentrasi $5 \mathrm{~g} / \mathrm{L}$ dengan waktu kontak 40 menit yaitu 75,13\%

Pengaruh jumlah adsorben merupakan parameter penting adsorpsi karena dapat menentukan kapasitas adsorben selama penambahan konsentrasi awal adsorbat. Adanya peningkatan jumlah adsorben cenderung meningkatkan daya serap terhadap adsorbat (Bhattacharyya and Gupta, 2008). Hal tersebut sesuai dengan hasil penelitian yang dilakukan oleh Krisnawati dkk (2013) dimana konsentrasi ion logam akan semakin menurun dengan bertambahnya jumlah adsorben yang digunakan. Jumlah adsorben yang semakin banyak akan memperluas penyerapan ion logam yang ada pada suatu larutan sehingga \% efektivitas adsorpsi juga akan semakin meningkat.

Pada kelima grafik diatas terjadi persamaan yaitu pada waktu 40 menit nitrat yang terserap adalah yang paling tinggi sehingga disimpulkan waktu kontak optimal penyerapan nitrat terjadi pada menit ke 40 dengan rata- rata penyerapan $73,75 \%$. Untuk penyerapan tertinggi terjadi pada konsentrasi $5 \mathrm{~g} / \mathrm{L}$ pada waktu kontak 40 menit dengan kadar penyerapan sebesar 75,13\% .

\section{KESIMPULAN DAN SARAN}

\section{Kesimpulan}

Dari hasil penelitian dan pembahasan yang dilakukan, dapat diperoleh kesimpulan sebagai berikut:

1. Zeolit termodifikasi surfaktan kationik amonium kuartener jenis hexadecyltrimethylammonium bromide (HDTMA-Br) dapat digunakan sebagai adsorben anion nitrat $\left(\mathrm{NO}_{3}{ }^{-}\right)$.

2. Waktu kontak optimum yang sesuai untuk adsorpsi anion nitrat $\left(\mathrm{NO}_{3}{ }^{-}\right)$oleh adsorben Zeolit termodifikasi surfaktan HDTMA-Br adalah 40 menit.

3. Konsentrasi surfaktan optimum yang sesuai untuk adsorpsi anion nitrat $\left(\mathrm{NO}_{3}{ }^{-}\right)$ oleh adsorben Zeolit termodifikasi surfaktan HDTMA-Br adalah $5 \mathrm{~g} / \mathrm{L}$ dengan efektitivitas penyerapan anion nitrat $\left(\mathrm{NO}_{3}{ }^{-}\right)$sebesar $75,13 \%$.

\section{Saran}

Saran dalam penelitian ini antara lain :

1. Bagi industri air minum yang diduga tercemar anion nitrat dapat menggunakan adsorben zeolit termodifikasi surfaktan kationik amonium kuartener hexadecyltrimethylammonium bromide (HDTMA-Br) sebagai salah satu alternatif menanggulangi pencemaran nitrat.

2. Perlu dilakukan penelitian lebih lanjut tentang regenerasi modifikasi zeolit alam dengan surfaktan HDTMA-Br sehingga mendapatkan zeolit yang berdaya guna lebih. 


\section{DAFTAR RUJUKAN}

Bhattacharyya, KG and Gupta, S.S. (2008). Immobilization of $\mathrm{Pb}(\mathrm{II}), \mathrm{Cd}(\mathrm{II})$ and $\mathrm{Ni}(\mathrm{II})$ Ions on Kaolinite and Montmorillonite Surfaces from Aqueous. Journal of Environmental Management. Vol.87, 45-58.

Emelda, L., Putri, S. M., \& Ginting, S. B. (2013). Pemanfaatan Zeolit Alam Teraktivasi Untuk Adsorpsi Logam $\mathrm{Cr}^{3+}$. Jurnal Rekayasa Kimia dan Lingkungan, Vol.2, No.4,166-172

Hongping, H., Ray, F.L., dan Jianxi, Z. (2004). Infrared Study of HDTMA+ Intercalated Montmorillonite. Elsevier

Khasanah, E.N. (2009). Adsorpsi Logam Berat Menggunakan Karbon Aktif Termodifikasi Zinc Klorida. Oseana. Yogyakarta: Universitas Gajah Mada.

Krisnawati, Jasinda dan Iriany. (2013). Penjerapan Logam Kadmium $\left(\mathrm{Cd}^{2+}\right)$ dengan Adsorben Cangkang Telur Bebek yang telah diaktivasi. Jurnal Teknik Kimia USU, Vol.2, No.3, 29-32.

Lestari, Dewi Yuanita. 2010. Kajian Modifikasi Dan Karakterisasi Zeolit Alam Dari Berbagai Negara. Prosiding seminar Nasional Kimia dan pendidikan, Tema: "Profesionalisme Peneliti dan Pendidik dalam Riset dan Pembelajaran yang Berkualitas dan Berkarakter", Universitas Yogyakarta, 30 Oktober 2010

Manampiring, A. E. (2009). Studi Kandungan Nitrat pada Sumber Air Minum Masyarakat Kelurahan Rurukan Kecamatan Tomohon Timur Kota Tomohon. Karya Ilmiah. Manado: Universitas SAM.

Marsidi, R. 2001. Zeolit Untuk Mengurangi Kesadahan Air. Jurnal Teknologi Lingkungan 2(1): 1-10

Masukume, M., Maurice S.O., Ochieng, A., \& Otieno, F. (2011). Nitrate Removal from Groundwater Using Modified Natural Zeolite. Journal of Water Research Commission. 36 (5), 655 - 662.

Novitasari, I. (2013). Modifikasi zeolit alam menggunakan surfaktan HDTMA-Br (hexadecyltrimethylammonium bromide) sebagai adsorben anion nitrat $\left(\mathrm{NO}_{3}{ }^{-}\right)$. Seminar kimia. Surakarta : Universitas Sebelas Maret

Rachman, F.A.A. (2009). Kandungan Nitrat Dan Timbal Pada Tanah Dan Kangkung Yang Diberi Perlakuan Air Limbah. Skripsi. Bogor: Institut Pertanian Bogor.

Syahruddin. (2000). Kelimpahan Plankton di Kawasan Batu Licin Kabupaten Kotabaru Provinsi Kalimantan Selatan. Fakultas Perikanan Universitas Lambung Mangkurat. Banjarbaru

Warsito, S., Sriatun, dan Taslimah. (2012). Pengaruh Penambahan Surfaktan Cetyltrimethylammonium Bromide (n-CTMABr) pada Sintesis Zeolit-Y. Kimia Anorganik, Jurusan Kimia, Fakultas MIPA Universitas 
Diponegoro, Semarang.

WHO. (2007). Nitrate and Nitrite in Drinking-Water. Background document for development of WHO Guidelines for Dringking-water Quality World Health Organization, Guidelines for Drinking Water Quality. Switzerland: WHO Press.

Weitkamp, J, and Puppe, L. (1999). Catalysis and Zeolites. Springer-Verlag, Berlin. 